\title{
Supporting Digital Innovations by Interdisciplinary Entrepreneurial Learning
}

\author{
Ileana Hamburg \\ Institut Arbeit und Technik \\ Westfälische Hochschule Gelsenkirchen, Germany.
}

\begin{abstract}
Digitalization signifies transformational or disruptive implications of digital technologies for businesses (new business and work models, new types of products/services, new types of customer). Digital technologies support new forms of innovation and entrepreneurial initiatives which hold implications at regional/national and societal and influence educators, policy making entities and other stakeholders. The formation of the entrepreneur as a person for digital transformation is important and considered, in a large part, to be due to learning. Entrepreneurship is "a process of new value creation" and digital entrepreneurship is understood as "a subcategory of entrepreneurship in which some or all of what would be physical in a traditional organization has been digitized". Existing research on the digitalization of innovation and entrepreneurship refers mostly to specific fields or disciplines (e.g., marketing, economics, information systems, operations, strategy) and arguably, limited effort has been spent so far on adopting a more interdisciplinary view of the underlying issues. Disruptive innovation and entrepreneurs are strongly connected. Entrepreneurs are often the ones that develop new products or services that change an entire industry and disruptive innovation has the potential to improve student/employees outcomes also during their entrepreneurial education and training. Particularly it happens by breaking boundaries for an interdisciplinary entrepreneurial learning. After the Introduction, the paper includes results of literature review and of interviews the author done with entrepreneurs within some European projects about different forms of innovation and entrepreneurship, particularly digital disruptive innovation and entrepreneurship. A review of literature about entrepreneurial learning and basis components, which characterize it, are given in part 3. It includes also experience of the author in teaching and training entrepreneurs. The last part of the paper presents some interdisciplinary new approaches within entrepreneurial learning oriented to disruptive, digital innovation and digital entrepreneurship. Developments within a European project with the participation of the author are also given.
\end{abstract}

Keywords: Entrepreneurship, Digitalization, Digital Entrepreneurship, Disruptive Innovation, Entrepreneurial Learning 


\section{INTRODUCTION}

There is no doubt that digitalization signifies transformational or disruptive implications of digital technologies for businesses (new business and work models, new types of products/services, new types of customer).

Recent studies have shown how digital technologies support new forms of innovation like disruptive ones, and entrepreneurial initiatives that cross traditional industry/sectoral boundaries and embrace networks ecosystems and communities. New digital forms of innovation and entrepreneurship also holds implications at a broader regional/national and societal levels with the potential to influence educators, policy making entities and other stakeholders (Burtch et al., 2018, Katz et al., 2014).

Existing research on the digitalization of innovation and entrepreneurship refers mostly to specific fields or disciplines (e.g., marketing, economics, information systems, operations, strategy) and arguably, limited effort has been spent so far on adopting a more interdisciplinary view of these issues.

Digital disruption (https://www.worldscientific.com/worldscibooks/10.1142/q0225) means not only displacing older companies, it's about innovating and inventing business to offer new products by using new digital technology to make them accessible to everyone. It also means the company with imagination and the best ideas will win.

The formation of the entrepreneur as a person for digital transformation is important and considered, in a large part, to be due to learning from experience (Deakins and Freel 1998, Rae and Carswell, 2001). Many entrepreneurs engage also in formal and informal learning activities, individually — such as enrolling on university courses (Davidsson and Honig 2003)—or collectively—such as forming peer learning groups (Mäkinen 2002).

Entrepreneurship is "the process of designing, launching and running a new business" (Hsieh and $\mathrm{Wu}, 2018$ ) with its distinct characteristic of "new value creation" (Hull et al., 2007). In connection with the developments of technology, other forms entrepreneurship is defined. Ferreira (Ferreira et al., 2016) opt for a broad conceptualization of technology entrepreneurship, suggesting that it is a combination of entrepreneurship and technology-based innovation., Beckman (Beckman et al., 2012) wrote that it is a type of entrepreneurship that aims to exploit opportunities related to advances in science and engineering. Technology entrepreneurship is an established concept in academia. The digitization of the "technology" not only changes its properties but also affects the overall technology entrepreneurship process. It has also impact on entrepreneurial processes in general and of new forms of entrepreneurship.

"Digital entrepreneurship" is understood as "a subcategory of entrepreneurship in which some or all of what would be physical in a traditional organization has been digitized" (Hull et al., 2007).

The connection between entrepreneurial learning and entrepreneurship was presented first by Schumpeter (1950) and then developed within an evolutionary framework, such as the evolutionary theory of the firm, the competence perspective in the theory of the firm (Foss and Mahnke 2002), or theories of organizational routines (Feldman and Pentland 2003; Becker 2004). 
Hamburg, I. (2020). Supporting Digital Innovations by Interdisciplinary Entrepreneurial Learning. Advances in Social Sciences Research Journal, 7(3) 8-17.

Disruptive innovation and entrepreneurs are strongly connected. Entrepreneurs are often the ones that develop new products or services that change an entire industry and disruptive innovation has the potential to improve student/employees outcomes also during their entrepreneurship education and training. Particularly it happens by breaking boundaries for an interdisciplinary entrepreneurial learning.

Entrepreneurial learning as a theoretical concept has been studied by many researchers and educators and has played a crucial role in the development of government policies aimed at fostering the 'knowledge-based economy (http://eprints.bournemouth.ac.uk/15080/1/241_Erd\%C3\%A9lyi_Final\%20Paper_313_The\%20 Matter\%20of\%20Entrepreneurial\%20Learning.pdf). It is a basis for education of entrepreneurs and supports digital entrepreneurship within the process of designing, lunching and running a new business in the digital era (Hull et al. 2007).

An increasing number of entrepreneurship courses are offered to students/employees within entrepreneurial learning from a specific field even though interdisciplinarity is important for entrepreneurship (Langemo, 2018; LERU, 2016).

After an introduction, the paper includes results of literature review and of interviews the author done with entrepreneurs within some European projects about different forms of innovation and entrepreneurship, particularly digital disruptive innovation and entrepreneurship.

A review of literature about entrepreneurial learning and basis components, which characterize it, are given in part 3. It includes also experience of the author in teaching and training entrepreneurs.

The last part of the paper presents some interdisciplinary new approaches within education by using entrepreneurial learning oriented to digital and disruptive innovation and digital entrepreneurship. Developments within a European project with the participation of the author are also given.

\section{DIGITAL DISRUPTIVE INNOVATION AND ENTREPRENEURSHIP}

For companies there are two main strategies to develop and expand their business in order to be competitive: disruptive or sustainable innovation.

Companies following sustainable innovation would like to improve the quality of the product they offer based on increasingly better experience. They are in the mainstream, but they target customers that move through higher levels of the market. Disruptive innovation, however, finds a niche and creates a new market, a value network that eventually moves up from the low end to the mainstream market. The companies using this type of innovation would like to attract as many customers as possible while developing a product that (due to digital technologies) is accessible to more people than what established companies offer.

While Christensen argued that disruptive innovations can hurt successful, well-managed companies, O'Ryan countered that "constructive" integration of existing, new, and forward-thinking innovation could improve the economic benefits of these same well-managed companies, once decision-making management understood the systemic benefits as a whole. Christensen et al. 
(2008) distinguish between "low-end disruption", which targets customers who do not need the full performance valued by customers at the high end of the market, and "new-market disruption", which targets customers who have needs that were previously unserved by existing incumbents.

Within the digital transformation sustainable innovation should be combined with, the predominant form of competition, digital disruption. New and original digital business models could be a reason why established companies have disappeared; they do anot dapt on time. The increase of digital technology and digital innovations in many domains is a catalyst for companies with fresh ideas to expand and displace other, old-fashioned ones. Such business should be flexiexible to keep up with digital trends, and established companies should be open to changes in order to stay competitive.

Some examples of digital technology companies in Europe and disruptive innovations are (eitdigital.eu/newsroom/accelerator):

\section{Sensative}

This Swedish company revolutionized the concept of smart cities and digital twin technology. They realized that a smart city was only as efficient as its operating system, so they created Yggio, an operating system for digital twins.

\section{Cybertrap}

Cybertrap offers just that: they are a cybersecurity company based in Vienna that specializes in deception technology for both governments and private enterprises.

\section{Medicus}

Medicus is an example of AI technology used to fill a niche that complete the service of a more traditional business. The interactive platform takes medical reports and health data, interprets them and translates them into advice and personalized explanations for the patient.

Referring entrepreneur and entrepreneurial learning, Landreth and Colander (1994) affirmed "...the real source of economic growth is fostered by the activities of the innovative entrepreneur not in the activities of the followers who are risk averse." Schumpeter (1950) emphasized that an entrepreneur is an individual who is both innovative. An entrepreneur has desire for achievement in any activity that one is engaged in (McClelland, 1961), being proactive instead of reactive (Miller, 1983) being innovative and creative (Drucker, 1985), being able to take risks (Brockhaus, 1982), being an opportunity identifier, moderate risk takers, and having an internal focus of control (Brockhaus, 1982). Recent developments in the context of entrepreneurship, possible combinations of technology and entrepreneurship have resulted within digital transformation.

The next table shows some topologies of entrepreneurship in connection with technology 
Table 1. Forms of technology and digital entrepreneurship Source Bailetti (2012), Gions (2017)

\begin{tabular}{|c|c|c|c|}
\hline Typology & $\begin{array}{l}\text { Technology Behind the } \\
\text { Opportunity }\end{array}$ & Key Activities in the Process & $\begin{array}{l}\text { Access to Resources and } \\
\text { Funding }\end{array}$ \\
\hline $\begin{array}{l}\text { Technology } \\
\text { Entrepreneurship }\end{array}$ & $\begin{array}{l}\text { New products based on } \\
\text { breakthroughs in research; } \\
\text { science-based advances through } \\
\text { specific knowledge in an } \\
\text { academic field } \\
\text { Example: Graphene }\end{array}$ & $\begin{array}{l}\text { Technology proof of concept: } \\
\text { first customer validation; activate } \\
\text { a global but niche market } \\
\text { (Clarysse et al., 2011) }\end{array}$ & $\begin{array}{l}\text { Public research grants and other } \\
\text { soft money sources } \\
\text { Venture capital attracted by } \\
\text { promising intellectual property } \\
\text { (Audretsch et al., 2012; Giones \& } \\
\text { Miralles, 2015) }\end{array}$ \\
\hline $\begin{array}{l}\text { Digital } \\
\text { Technology } \\
\text { Entrepreneurship }\end{array}$ & $\begin{array}{l}\text { New products based on ICT } \\
\text { technologies only; making smart } \\
\text { devices using the possibilities of } \\
\text { Internet of Things } \\
\text { Example: Smartphone }\end{array}$ & $\begin{array}{l}\text { Use of existing technologies: } \\
\text { market validation, traction, and } \\
\text { growth, scalability }\end{array}$ & $\begin{array}{l}\text { Business angels; seed and } \\
\text { venture capital; stock market } \\
\text { Crowdfunding: reward and } \\
\text { equity (Gedda et al., 2016) }\end{array}$ \\
\hline $\begin{array}{l}\text { Digital } \\
\text { Entrepreneurship }\end{array}$ & $\begin{array}{l}\text { New products and services based } \\
\text { on the Internet. Services running } \\
\text { only in the cloud; using big data } \\
\text { or artificial intelligence. } \\
\text { Example: Snapchat }\end{array}$ & $\begin{array}{l}\text { Technology as an input factor: } \\
\text { high growth ambitions (Wallin et } \\
\text { al., 2016); stay ahead of } \\
\text { competitors; be the dominant } \\
\text { player in the category }\end{array}$ & $\begin{array}{l}\text { Business angels; seed and } \\
\text { venture capital; stock market } \\
\text { Equity crowdfunding (Tomczak \& } \\
\text { Brem, 2013) }\end{array}$ \\
\hline
\end{tabular}

Digital entrepreneurship can be considered also as the reconciliation of traditional entrepreneurship (Le Dinh et al, 2018) with the new way of creating and doing business in the digital era.

Digital entrepreneurship is a phenomenon, which arose through technological assets like internet and information and communications technology (Le Dinh et al., 2018). Entrepreneurial activity that transfers an asset, service or major part of the business into digital can be characterized as digital entrepreneurship. Products, marketing activities and workplace are major differentiation criteria between digital and non-digital entrepreneurs.

The main advantage of digital entrepreneurship is that own business could be managed from anywhere in the world, provided access to the internet.

Other advantages are:

- More flexible hours

- Cost savings

- Easiness of reaching many people

- Easily scalable business

The DigComp 2.0 framework (https://ec.europa.eu/jrc/en/digcomp/digital-competenceframework) identifies the key components of digital competence necessary in digital entrepreneurship:

- Information and data literacy i.e. articulate information needs, locate and retrieve digital data, information and content, judge the relevance of the source and its content, store, manage, and organize digital data, information and content. 
- Communication and collaboration i.e. interact, communicate and collaborate through digital technologies while being aware of cultural and generational diversity, participate in society through public and private digital services and participatory citizenship, manage one's digital identity and reputation.

- Digital content creation i.e. create and edit digital content, improve and integrate information and content into an existing body of knowledge while understanding how copyright and licenses are to be applied, know how to give understandable instructions for a computer system.

- Safety i.e. protect devices, content, personal data and privacy in digital environments, protect physical and psychological health, and be aware of digital technologies for social well-being and social inclusion and of the environmental impact of digital technologies and their use.

- Problem solving i.e. identify needs and problems resolve conceptual problems and problem situations in digital environments, use digital tools to innovate processes and products, keep up to date with the digital evolution.

\section{INTERDISCIPLINARY ENTREPRENEURIAL LEARNING}

The European definition of entrepreneurial learning includes the development of entrepreneurial attitudes, skills and knowledge that enable the individual to turn creative ideas into action. Entrepreneurship is not only related to economic activities and business creation, but more widely to creating value in all areas of life and society, with or without a commercial objective (http://www.thelearninglab.nl/?dt_portfolio=36345).

Entrepreneurial learning:

- creates conditions for job creation and a healthy economy

- stimulates innovation and the capacities to deal with exponential change and globalization

- engages and motivates students through relevant learning experiences for education, life and work.

- empowers people to create value for society and deal with societal challenges.

Peter Erdélyi underlines that entrepreneurial learning is

- an observable phenomenon, something entrepreneurs engage in or are associated with

- a concept that has started to receive increasingly explicit articulation in academic literature in the past decade and which has been implicit in the literature since Schumpeter (1950)

- a core policy objective in developed Western countries implemented through funded programs targeted at entrepreneurs (https://www.researchgate.net/publication/228419882 The Matter of Entrepreneurial Learning A Literature Review).

Entrepreneurial learning is still a relatively new area of study, presenting more interests since Becker and Knudsen (2009) associate it i.e. with globalization, the spread of new ICTs, and the revival of small business. The confrontation of entrepreneurship studies and organizational learning literature (Dierkes 2001; Easterby-Smith and Lyles 2003), which was done parallel during the past decade, raised the interest in entrepreneurial learning.

Entrepreneurial learning has emerged as an important area of inquiry in relation to both the academic studies of entrepreneurship and the practical development of new entrepreneurs. There 
Hamburg, I. (2020). Supporting Digital Innovations by Interdisciplinary Entrepreneurial Learning. Advances in Social Sciences Research Journal, 7(3) 8-17.

exist theoretical approaches focused on diverse aspects of entrepreneurial learning divided into two main groups, depending on their analyzing object: those focusing on the individual entrepreneur and those focusing on the organizational context (https://www.researchgate.net/publication/228419882_The_Matter_of_Entrepreneurial_Learnin g_A_Literature_Review). The first approach has as object the personal learning experience and the cognitive capabilities of the „entrepreneurial individuals ", the second sees entrepreneurship as a collective activity and at various scales, from the single firm and its immediate network towards the national system of innovation.

In the recent years the interest in entrepreneurial learning has been experiencing a significant growth and literature in this area is brimming with examples of the application of interactive teaching techniques to it. The interdisciplinary (also called cross-disciplinary) problem-based learning and experiential (also called action learning and situational learning) approaches for entrepreneurial learning have gained interest among academicians and educators. is brimming with examples of the application of interactive teaching techniques to entrepreneurship (Langemo, 2018).

But many studies conducted on entrepreneurial learning refer to a specific field of study, such as business and management sciences and technology or computer engineering (Nambisan et al., $2017,2019)$. There exist theories and pedagogical approaches promoting interdisciplinary learning, but it seems that current academic organizational structures support instruction that compartmentalizes disciplines, instead of providing students with the tools for integrating knowledge. Christensen et al. (2008) explain that colleges and universities are in the midst of a complex crisis and are, therefore, expected to rethink their traditional goals and practices, in the face of competition from newer alternatives such as online education.

In an interdisciplinary course student integrate information from different disciplines and subject areas. As defined by Golding (2009), interdisciplinarity is balancing the employment of multiple academic disciplines into one activity to provide students with a deeper understanding or, viable solutions that creatively accommodates different perspectives. Students develop an interdisciplinary understanding and learn to integrate established areas of expertise and disciplinespecific ways of thinking, to increase cognitive abilities and critical thinking beyond that experienced through single disciplinary means (Boix \& Duraising, 2007).

Referring digital entrepreneurship its importance increased but teaching and learning of digital entrepreneurship is not only a current hot topic and should be integrated in entrepreneurial learning programs.

In addition to the equipment, certain features are essential if someone will learn to be a digital entrepreneur:

- Curiosity: in order to undertake on the internet, one of the needs is to cultivate own curiosity, because only researching a lot about the market and the behavior of consumers for future business offers a solution that adds value to people's lives.

- Willingness to study/become specialized: read news about market daily. Over time the need to specialize in a theme that affects your business the most. 
- Wanting to help people: "Entrepreneurship is associated much more with identifying problems and opportunities to implement an idea that causes positive impacts than being innovative and creating something never seen before."

- Knowing Advantages of digital entrepreneurship.

\section{EXAMPLE}

In 2018, the authors started the Erasmus + project REINNOVATE, aimed to translate policies to support digital entrepreneurship into practice by focusing on cultivating an entrepreneurial learning culture in small companies (Hamburg et al., 2018).

Prior to the starting the project, the REINNOVATE consortium conducted a survey to determine the challenges and needs of 142 SMEs in Europe in order to be innovative, to grow and to cope with digital changes. It was found that $97 \%$ of asked companies want to become more innovative and use digital technology but corresponding competences and suitable entrepreneurial learning facilities are missing. Other barriers to innovation are resources (60\%) i.e. specialized equipment, staff. About 38\% of SMEs answered that skills to use digital technologies to deliver new innovative products and services or new digital innovative business models and disruptive innovations are missing. Workplace oriented research skills were seen as significantly important with, $87 \%$ of SME identifying research skills as important or very important to their organization, however there is a significant skills gap with $62 \%$ of SMEs having no research skills. To address such missing skills gaps the Reinnovate consortium with higher education institutes and research organizations, chamber of commerce and SME representative bodies developed an entrepreneurial training program (Hamburg, 2019). The employees learn within the interdisciplinary training program consisting of four modules developed within the project how to be successful and are encouraged to develop and evaluate small innovative business models including disruptive ones.The training program is supported by an interactive e-learning platform, interdisciplinary trainers and mentors. The main used method is interdisciplinary problem-based learning (iPBL). Employees are engaged in effective interactive content, interactive exercises in 'accountancy', find and use information and data (Hamburg et al., 2019).

\section{CONCLUSIONS}

This paper provides an overview of entrepreneurship forms relevant to disruptive innovations and new businesses focused on offering new products and services in response to digital developments. Digital entrepreneurship means creating new ventures and transforming existing businesses by developing novel digital technologies and/or novel usage of such technologies, (European Commission, 2015). Digital entrepreneurship has been viewed as a critical pillar for economic growth, job creation and innovation by many countries including the Member States of the European Union. However, digital entrepreneurial capacity depends largely on digital entrepreneurial behaviour, culture, and strategies as well educational approaches, topics that are less researched. Disruptive innovation has a significant impact on a market and on the economic activity of firms in that market being focused on innovations as opposed to their novelty. Entrepreneurial learning has emerged as a promising area of research at the interface between learning and the entrepreneurial context with the importance of a specific processes of learning that occur in this context. 
Hamburg, I. (2020). Supporting Digital Innovations by Interdisciplinary Entrepreneurial Learning. Advances in Social Sciences Research Journal, 7(3) 8-17.

In the literature, it is not more about interdisciplinary aspects of entrepreneurial learning and the role of learning in the entrepreneurial process particularly within digital entrepreneurship and disruptive innovations; this is a future research topic of the authors together with aspects of culture and employees behaviour in this context.

\section{Aknowledgment}

This research is part of the project Reinnovate

\section{References}

Bailetti, T. (2012). Technology Entrepreneurship: Overview, Definition, and Distinctive Aspects. Technology Innovation Management Review, 2(2): 5-12. http://timreview.ca/article/520

Beckman, C. M., Eisenhardt, K., Kotha, S., Meyer, A., \& Rajagopalan, N. (2012). Technology Entrepreneurship. Strategic Entrepreneurship Journal, 6(2): 89-93. https://doi.org/10.1002/sej.1134

Becker, M. C. (2004). 'Organizational Routines: A Review of the Literature.' Industrial and Corporate Change, 13 (4): 643-678.

Becker, M. C. and Knudsen, C. (2009). 'Schumpeter and the Organization of Entrepreneurship'. The Oxford Handbook of Sociology and Organization Studies: Classical Foundations. P. S. Adler. Oxford, Oxford University Press: 307-326.

Boix Mansilla, V. \& Duraising, E. (2007). Targeted assessment of students' interdisciplinary work: An empirically grounded framework proposal. Journal of Higher Education, 78(2), 215-237.

Brockhaus, R.H. (1982), "The psychology of the entrepreneur", Encyclopedia of Entrepreneurship, Prentice-Hall, Englewood Cliffs, NJ, pp. 39-56.

Burtch, G., Carnahan, S., Greenwood, B., (2018). Can you gig it? An empirical examination of the gig economy and entrepreneurship. Manage. Sci. 64 (12), 5461-5959

Christensen, C.M., Horn, M.B., Johnson, C.W. \& A .COM (firm). "Disrupting class: How disruptive innovation will change the way the world learns", McGraw-Hill, New York. 2008

Deakins, D. and Freel, M. (1998). 'Entrepreneurial Learning and the Growth Process in SMEs.' The Learning Organization, 5 (3): 144-155Deakins, D., O'Neill, E., et al. (2000). 'Executive Learning in Entrepreneurial Firms and the Role of External Directors.' Education + Training, 42 (4/5): 317-325.

Dierkes, M. (2001). Handbook of Organizational Learning and Knowledge. Oxford, Oxford University Press.

Easterby-Smith, M. and Lyles, M. A. (2003). The Blackwell Handbook of Organizational Learning and Knowledge Management. Oxford, Blackwell.

European Commission (2015). Digital Entrepreneurship Monitor. Retrieved from https://ec.europa.eu/growth/toolsdatabases/dem/monitor/statistics\#/home

Feldman, M. S. and Pentland, B. T. (2003). 'Reconceptualizing Organizational Routines as a Source of Flexibility and Change.' Administrative Science Quarterly, 48 (1): 94118.

Ferreira, J. J. M., Ferreira, F. A. F., Fernandes, C. I. M. A. S., Jalali, M. S., Raposo, M. L., \& Marques, C. S. (2016). What Do We [Not] Know About Technology Entrepreneurship Research? International Entrepreneurship and Management Journal, 12(3): 713-733. https://doi.org/10.1007/s11365-015-0359-2

Foss, N. and Mahnke, V. (2002). Competence, Governance, and Entrepreneurship: Advances in Economic Strategy Research. Oxford, Oxford University Press.

Gions, F., \& Oo, P. (2017). How Crowdsourcing and Crowdfunding are Redefining Innovation

Management. In A. Brem \& E. Viardot (Eds.), Revolution of Innovation Management: 43-70. London: Palgrave Macmillan UK. https://doi.org/10.1057/978-1-137-57475-6_3 
Golding, C. (2009). Integrating the disciplines: Successful interdisciplinary subjects. Centre for the Study of Higher Education. Available in form http://www.cshe.unimelb.edu.au/ resources_teach/curriculum_design/docs/Interdisc_Guide.pdf

Hamburg, I., O'Brien, E., Vladut, G. (2018). Workplace-oriented research and mentoring of entrepreneurs: cooperation university - industry. Archives of business research, no. 6, 243-25.

Hamburg, I., O'Brien, E., Öz, F. (2019): Chapter 2: Entrepreneurship \& research skills in SMEs. In: Dirksen, Daan: The power of entrepreneurship. New York: Nova Science Publishers, p.45-76

Hamburg, I. (2019): Implementation of a digital workplace strategy to drive behavior change and improve competencies. In: Strategy and behaviors in the digital economy strategy and behaviors in the digital economy. London: IntechOpen, $16 \mathrm{p}$

Hull, C.E., Hung, Y.-T.C., Hair, N., Perotti, V. and DeMartino, R. (2007), "Taking advantage of digital opportunities: a typology of digital entrepreneurship", International Journal of Networking and Virtual Organizations, Vol. 4 No. 3, pp. 290-303

Katz, R., Koutroumpis, P., Martin Callorda, F., (2014). Using a digitization index to measure the economic and social impact of digital agendas. Info 16 (1), 32-44Kolb, D. A. (1984). Experiential Learning: Experience as the Source of Learning and Development. Englewood Cliffs; London, Prentice-Hall.

Landreth, H. and Colander, D. (1994), History of Economic Thought, 3rd ed., Houghton Mifflin, Toronto

Langemo, B. (2018). An Interdisciplinary Approach to Creating Entrepreneurial Learning Environments. The NISOD Papers, 9, 2018.

Le Dinh, T., Vu, M.C. and Ayayi, A. (2018), “Towards a living lab for promoting the digital entrepreneurship process", International Journal of Entrepreneurship, Vol. 22 No. 1, pp. 1-17

LERU (2016), Interdisciplinarity and the 21st century research-intensive university. 2016, p 7):

Levenburg, N.M., Lane, P.M. \& Schwarz, T.V. (2006). Interdisciplinary dimensions in entrepreneurship. Journal of Education for Business, 81(5), 275-281.

Mäkinen, H. (2002). 'Intra-Firm and Inter-Firm Learning in the Context of Start-up Companies.' The International Journal of Entrepreneurship and Innovation, 3 (1): 35-43.

McClelland, D.C. (1961), The Achieving Society, D. Van Nostrand Company, Inc., Princeton,

Miller, D. (1983), "The correlates of entrepreneurship in three types of firms”, Management Science, Vol. 29 No. 7, pp. 770-91.

Nambisan, S., Lyytinen, K., Majchrzak, A., Song, M., (2017). Digital innovation management: reinventing innovation management research in a digital world. Mis Q. 41 (1), 223-238.

Nambisan, S., Zahra, A., Luo, Y., (2019). Global platforms and ecosystems: implications for O’Brien, E., Carroll, L. (2015). A report on how problem-based learning and ICT can support SMEs in Europe. Retrieved from

http://www.archimedes2014.eu/doc/reports/European\%20report\%20on\%20SMEs.pdf

Rae, D. and Carswell, M. (2001). 'Towards a Conceptual Understanding of Entrepreneurial Learning.' Journal of Small Business and Enterprise Development, 8 (2): 150-158.

Schumpeter, J.A. (1950), Capitalism, Socialism, and Democracy, 3rd ed., Harper \& Row, New York, NY. 